\title{
ESCOLA, FAMÍLIA E BILINGUISMO NA EDUCAÇÃO DE SURDOS
}

Adriana Moreira de Souza Corrêa, Universidade Federal de Campina Grande (UFCG)

adriana.korrea@gmail.com.br

\section{PALAVRAS-CHAVE: Escola; Família; Bilinguismo.}

\section{INTRODUÇÃO}

A família é, em geral, o primeiro grupo social que a criança interage e, a partir da vivência nesta coletividade, internaliza padrões de comportamento, bem como partilha um sistema linguístico que mediará a assimilação de conhecimentos durante toda a vida. Nesta perspectiva, o desenvolvimento linguístico inicia na família e se estende aos demais grupos sociais os quais a criança interage, contudo, Slomski (2010) adverte que 95\% dos surdos brasileiros nascem em famílias de ouvintes que não são usuárias de Língua de Sinais, ou seja, estas crianças relacionam-se em um grupo que utiliza um sistema linguístico que não é capaz de ser adquirido naturalmente pela criança surda.

Daneluz (2008) e Garcia (2015) discorrem que o ambiente familiar, sua organização, as representações e as interações podem interferir no desempenho do educando na escola, a medida que é neste espaço que, a maioria das crianças, adquirem os primeiros conhecimentos sobre si e do mundo. Os estudiosos destacam que, ao chegarem à escola, os estudantes trazem uma infinidade de saberes oriundos das relações desenvolvidas no meio social onde vivem. Entretanto, Garcia (2015) ressalta que a ausência de uma língua compartilhada com as pessoas com as quais eles interagem cotidianamente pode, além de interferir na compreensão do mundo, atuar negativamente na representação de si.

Deste modo, compreendemos que, para possibilitar a ampliação das capacidades comunicativas da criança, bem como para desenvolver o seu aprendizado, o educando precisa partilhar uma língua com a sua família. Tratando-se de ouvintes não usuários da Libras, entendemos que a escola que conta com profissionais capacitados (que atuam na classe regular) e especializados (que realizam o Atendimento Educacional Especializado - AEE) constitui-se em um espaço de esclarecimento e de fortalecimento de laços entre os membros deste grupo familiar. 


\section{METODOLOGIA}

A referida pesquisa foi impulsionada pela seguinte questão: Como a relação entre a família e a escola contribuem para o aprendizado da criança surda? Para discutir a questão realizamos uma pesquisa de abordagem qualitativa, com o objeto de apresentar as contribuições da escola para a continuidade do aprendizado linguístico e dos conhecimentos universais para a criança surda. Visamos também identificar a relevância do apoio desta última para a ampliação dos conteúdos e habilidades desenvolvidos pelo estudante na escola considerando, para isso, o respeito à sua singularidade linguística. Por esta razão, realizamos uma pesquisa bibliográfica, buscando conteúdos disponíveis em livros, artigos científicos e outros trabalhos disponíveis em sites, a fim de conhecer os conhecimentos divulgados sobre o assunto. Simultaneamente às leituras, foram elaborados apontamentos (através de tópicos) com as informações relevantes a serem discutidas e, posteriormente, estes registros foram transformados quadros que visavam categorizar as informações que serão apresentadas a seguir.

\section{ESCOLA, FAMÍLIA E O APRENDIZADO DO SURDO}

O ser humano é um ser constituído pela linguagem. Como afirma Garcia (2015), a natureza humana e não a sociedade é que definirá a modalidade linguística que o indivíduo desenvolverá para a comunicação. Para o autor, a manifestação da linguagem que for reconhecida pelo cérebro (seja ela visual-gestual ou oral-auditiva) é que determinará o sistema linguístico que possibilitará o desenvolvimento individual e a interação social do indivíduo. Desta maneira, é necessário que a família e a escola colaborem para proporcionar a pessoa surda uma educação bilíngue para surdos na qual a Língua Brasileira de Sinais - Libras e a Língua Portuguesa sejam as línguas de instrução.

Slomski (2010) destaca que a aquisição da Libras deve iniciar na família, com os pais que são os educadores naturais da criança surda, tendo em vista que este sistema de comunicação favorece o desenvolvimento linguístico e socioafetivo da criança, possibilitando a constituição de uma identidade afirmativa pelo representante desta minoria linguística. No entanto, a pesquisadora ressalta que, em geral, as famílias ouvintes que têm um filho surdo não dispõe de informações suficientes sobre a relevância da Libras para o desenvolvimento da pessoa surda e não são capazes de interagir por meio desta língua. Neste sentido, a escola pode colaborar à medida que dispõe de profissionais que, ao cursarem a disciplina de Libras 
(ação prevista, no Decreto $\mathrm{n}^{\mathrm{o}}$ 5.626/2006 para a formação de todos os licenciados), tiveram contato com a Língua de Sinais e conhecem a sua relevância para a formação escolar e social do surdo, sendo capaz de esclarecer a família sobre o uso deste sistema. Associado a este profissional, temos o docente que atua na Sala de Recursos Multifuncional e promove o AEE, que é especializado nesta área e pode contribuir indicando espaços de capacitação e esclarecendo os pais sobre ações que devem ser realizadas a fim de que os conteúdos trabalhados e as relações constituídas na escola tenham continuidade nas práticas familiares.

Em contrapartida, a família pode observar a efetividade das práticas desempenhadas pela escola e contribuir com a identificação das dificuldades e das estratégias exitosas utilizadas por esta instituição educacional.

\section{CONSIDERAÇÕES FINAIS}

Diante do exposto, consideramos que a educação da criança surda efetiva-se com o respeito à sua forma de compreensão do mundo, que é visual e pela garantia do direito à aquisição da Libras e da Língua Portuguesa na modalidade escrita. No entanto, para que isso ocorra é necessária a efetivação da parceria entre a família e a escola para que as conquistas do aluno sejam celebradas conjuntamente e as dificuldades discutidas e superadas a partir do trabalho que se inicia na escola e encontra, no ambiente familiar, continuidade.

\section{REFERÊNCIAS}

BRASIL. Decreto n⿳ 5.626, de 22 de dezembro de 2005. Disponível em: < https://presrepublica.jusbrasil.com.br/legislacao/96150/decreto-5626-05>. Acesso em: 11 de agosto de 2017.

DANELUZ, M. Escola e Família: duas realidades, um mesmo objetivo. In: Anais do I Simpósio Nacional de Educação e XX Semana de Educação. Comissão científica Adrian Alvarez Estrada [et al.] — Cascavel, PR, 10 a 12 de novembro de 2008. Disponível em: < http://www.unioeste.br/cursos/cascavel/pedagogia/eventos/2008/ficha.html>. Acesso em: 11 de agosto de 2017.

GARCIA, E. C. O que todo Pedagogo precisa saber sobre Libras?: os principais aspectos e a importância da Língua Brasileira de Sinais. 2ª ed. Rio de Janeiro: Wak Editora, 2015.

SLOMSKI, V. G. Educação Bilíngue para Surdos: concepções, implicações e práticas pedagógicas. Curitiba: Juruá, 2010. 